Mr Dejan Ivković, kapetan I klase, dipl. inž. Generalštab Vojske Srbije - Uprava J-2,

\section{MODIFIKACIJA KONVENCIONALNIH RADARA NA BAZI KONCEPTA SOFTVERSKOG RADARA}

UDC: $621.396 .96: 004.42$

Rezime:

U radu su projektovani softverski modeli pojedinih funkcionalnih blokova radara, čime se stvorila pogodna osnova za poboljšanje performansi postojećih konvencionalnih radara. Primenom koncepta softverskog radara mogu se unaprediti karakteristike i povećati fleksibilnost konvencionalnih radara, kao i implementirati potpuno nove funkcije koje znatno unapređuju njegove performanse. Svi softverski modeli projektovani su u programskom paketu MATLAB. Takođe, opisana je struktura i karakteristike konvencionalnog radara ŽIRAFA, koji je softverski modelovan. Pored toga, opisan je način softverske realizacije memorije RANGE BIN, Doplerovog filtera i detaljno opisan matematički model procesora CFAR.

Ključne reči: softverski radar, konvencionalni radar ŽIRAFA, procesor CFAR, Doplerov filter.

\title{
CONVENTIONAL RADARS MODIFICATION ON THE SOFTWARE RADAR CONCEPT BASIS
}

Summary:

Software models of some functional radar units are projected in this paper and proper platform for performance improving of existent conventional radars is created. Feature improving and flexibility increasing of conventional radars can be upgraded with application of software radar concept and totally new functions can be implemented which also upgraded its performances. All software models are projected in MATLAB program. Also structure and performances of the conventional radar GIRAFFE, which is modeled by software, are described. Additionally, way of the RANGE BIN memory and Doppler filter software realization are described. CFAR mathematical model is presented detailed.

Key words: software radar, conventional radar GIRAFFE, CFAR procesor, Doppler filter.

\section{Uvod}

Savremeni razvoj radarske tehnologije, a posebno razvoj metoda obrade radarskih signala posredstvom signal-procesora $\mathrm{i}$ računara, omogućio je mnogo širu primenu radara nego što je bila njegova prvobitna namena, tj. otkrivanje i praćenje ciljeva. Danas savremeni radari obavljaju mnoge funkcije. Pri tome, treba ukazati na činjenicu da se ove funkcije mogu obavljati pojedinačno, specijalizovanim radarskim uređa- jima, a moguće je da jedan višefunkcionalan radar obavlja više funkcija u vidu tzv. modova rada. Tipičan primer predstavlja višefunkcionalni avionski radar $\mathrm{s}$ većim brojem modova rada, kao što su: osmatranje, automatsko praćenje, vođenje raketa, snimanje terena i sl. Stariji radari mahom su bili specijalizovani po nameni, pa se govorilo o osmatračkim, nišanskim, meteorološkim radarima i sl. Danas je logičnije govoriti o mogućim funkcijama radara, s obzirom na pomenutu višefunkcionalnost. 
Pod pojmom konvencionalni radar podrazumeva se monostatički impulsni radar koji koristi eho signal za lociranje cilja. Kod ovakvog radara predajnik i prijemnik su na istom mestu, što znači da postoji jedna primopredajna antena. Funkcije većine konvencionalnih radara starije tehnološke generacije hardverski su predefinisane, tako da su otežane mogućnosti izvođenja modifikacija radi poboljšanja performansi. S napretkom tehnike digitalne obrade signala i signal-procesorskih tehnologija, teorijski i praktično je razrađen koncept softverskog radija. Njegova realizacija podrazumeva da deo hardvera klasičnog radija treba zameniti sa signalprocesorskom platformom, na kojoj se softverski implementira deo funkcija radija. Koncept softverskog radara predstavlja specifičnu primenu softverskog radija. U ovom radu analizirane su mogućnosti modelovanja konvencionalnih radara $\mathrm{kroz}$ primenu koncepta softverskog radara, a radi poboljšanja njihovih performansi. Ukoliko se realizuje ova ideja, stvara se pogodna platforma za unapređivanje karakteristika postojećih konvencionalnih radara primenom modernih tehnika obrade radarskog signala.

Cilj ovog rada je projektovanje softverskog modela pojedinih funkcionalnih blokova radara, čime bi se stvorila pogodna platforma za poboljšanje performansi postojećih konvencionalnih radara.

\section{Struktura i karakteristike konvencionalnog radara koji se softverski modeluje}

Da bi se analizirala ideja o primeni koncepta softerskog radara kod konvencionalnih radara upotrebljen je konvenci- onalni radar ŽIRAFA, čiji je proizvođač poznata švedska kompanija Erikson (Ericsson). ŽIRAFA je impulsni Doplerov osmatračko-akvizicijski radar s digitalnom obradom signala, proizveden 1986. godine. Kabina radara smeštena je na motorno vozilo, pa radarski položaj može biti izabran proizvoljno, za razliku od stacionarnih radara. Namenjen je da u okviru sistema protivvazdušne odbrane (PVO) detektuje i prati niskoleteće ciljeve. Pri detekciji određuje daljinu i azimut cilja. Brzina cilja se ne meri već grubo procenjuje preko kola za praćenje, a ciljevi se po brzinama svrstavaju u samo tri grupe. Radne frekvencije radara su unutar C-opsega frekvencija, a maksimalni domet iznosi $40 \mathrm{~km}$. Digitalnom obradom signala potiskuje se klater, pa se u normalnom režimu rada na pokazivaču prikazuju samo pokretni ciljevi, što olakšava rad operaterima.

U tabeli 1 prikazane su osnovne tehničke karakteristike radara ŽIRAFA. Vidi se da, u zavisnosti od širine predajnog impulsa, ŽIRAFA može meriti daljine do 20 ili $40 \mathrm{~km}$. Ako je izabrana širina predajnog impulsa od $3 \mu \mathrm{s}$, domet će iznositi $20 \mathrm{~km}$, a ako je širina $6 \mu \mathrm{s}$, domet će biti maksimalnih $40 \mathrm{~km}$. Frekvencije nosioca su u opsegu od 5,4 do 5,9 GHz. Kao pojačavač snage koristi se TWT cev, koja obezbeđuje da izračena snaga u jednom impulsu bude $15 \mathrm{~kW}$. Impulsna frekvencija (PRF) promenljiva je i može se menjati svake sekunde, od jednog do drugog obrtaja antene (,,promenljiva PRF“), ili od jednog do drugog predajnog impulsa (,višestruka PRF“). Prijemnik je superhetorodinskog tipa s međufrekvencijom od $30 \mathrm{MHz}$. 
Radar ŽIRAFA može detektovati ciljeve koji se kreću brzinama od 15 do 900 $\mathrm{m} / \mathrm{s}$, sa rezolucijom po daljini od $740 \mathrm{~m} \mathrm{u}$ modu rada s maksimalnim dometom. Ova rezolucija je za današnje prilike veoma mala, a rezolucija po azimutu iznosi $4,7^{\circ}$.

Antena radara je u obliku delimičnog paraboloida. Dijagram zračenja je kosekans na kvadrat sa širinom snopa po azimutu $2,1^{\circ}$ i po elevaciji $9,2^{\circ}$. Dobitak antene je $\mathrm{G}=28 \mathrm{~dB}$, a visina od tla $13 \mathrm{~m}$.

Tabela 1

Osnovne tehničke karakteristike radara ŽIRAFA

\begin{tabular}{|c|c|c|}
\hline \multicolumn{2}{|c|}{ Karakteristika } & Vrednost \\
\hline \multicolumn{2}{|l|}{ Tip radara } & $\begin{array}{l}\text { impulsni Doplerov radar } \\
\text { sa digitalnom obradom } \\
\text { signala }\end{array}$ \\
\hline \multicolumn{2}{|l|}{ Opseg daljine } & 0-20 km, ili $0-40 \mathrm{~km}$ \\
\hline \multicolumn{2}{|l|}{ Frekventni opseg } & C-opseg, 5,4-5,9 GHz \\
\hline \multicolumn{2}{|l|}{ Pojačavač snage } & $\begin{array}{l}\text { cev sa progresivnim } \\
\text { talasom (TWT) }\end{array}$ \\
\hline \multicolumn{2}{|l|}{ Impulsna snaga } & $15 \mathrm{~kW}$ \\
\hline \multicolumn{2}{|l|}{ Širina impulsa } & $3 \mu \mathrm{s}$ ili $6 \mu \mathrm{s}$ \\
\hline \multicolumn{2}{|c|}{ Impulsna frekvencija (PRF) } & $\begin{array}{l}\text { promenljiva PRF ili } \\
\text { višestruka PRF }\end{array}$ \\
\hline \multicolumn{2}{|l|}{ Međufrekvencija } & $30 \mathrm{MHz}$ \\
\hline \multicolumn{2}{|l|}{ Opseg brzina ciljeva } & $15-900 \mathrm{~m} / \mathrm{s}$ \\
\hline \multirow{2}{*}{$\begin{array}{l}\text { Rezolucija dva } \\
\text { cilja iste jačine }\end{array}$} & po daljini & $740 \mathrm{~m}$ \\
\hline & po azimutu & $4,7^{\circ}$ \\
\hline \multicolumn{2}{|c|}{ Brzina obrtanja antene } & $1 \mathrm{obr} / \mathrm{s}$ \\
\hline \multirow{2}{*}{\begin{tabular}{|l|} 
Širina snopa \\
dijagrama zračenja
\end{tabular}} & po azimutu & $2,1^{\circ}$ \\
\hline & po elevaciji & $9,2^{\circ}$ \\
\hline \multicolumn{2}{|l|}{ Pojačanje antene } & $28 \mathrm{~dB}$ \\
\hline \multicolumn{2}{|l|}{ Visina antene od tla } & $13 \mathrm{~m}$ \\
\hline \multirow[t]{2}{*}{ Napajanje } & agregatom & VW Diesel \\
\hline & \begin{tabular}{|l|} 
spoljnom \\
trofaznom \\
mrežom \\
\end{tabular} & $\begin{array}{l}220 \mathrm{~V}, 50 \mathrm{~Hz} \text { i } 200 \mathrm{~V}, \\
400 \mathrm{~Hz}\end{array}$ \\
\hline \multicolumn{2}{|l|}{ Dužina } & $6800 \mathrm{~mm}$ \\
\hline \multicolumn{2}{|l|}{ Širina } & $2490 \mathrm{~mm}$ \\
\hline \multicolumn{2}{|l|}{ Visina, stub spušten } & oko $3,5 \mathrm{~m}$ \\
\hline \multicolumn{2}{|l|}{ Masa } & $7450 \mathrm{~kg}$ \\
\hline
\end{tabular}

Pošto radar ŽIRAFA spada u mobilne radare, za napajanje koristi agregat koji se nalazi u sklopu kabine. Agregat stvara standardni trofazni naizmenični napon od $220 \mathrm{~V}$, frekvencije $50 \mathrm{~Hz}$ i specijalni trofazni naizmenični napon od $200 \mathrm{~V}$, frekvencije $400 \mathrm{~Hz}$.
Predajni signal generiše se u kristalnom oscilatoru frekvencije $120 \mathrm{MHz}$, a zatim mu se frekvencija umnožava u nekoliko koraka, dok se ne dobije odgovarajuća frekvencija u C-opsegu. Blok koji obavlja ovu funkciju nazvan je RF generator. Njegovo mesto prikazano je na uprošćenoj blok-šemi radara ŽIRAFA na slici 1. Visokofrekventni signal koji je generisan u RF generatoru dalje se pretvara u impulsni visokofrekventni signal i pojačava u TWT pojačavaču. Na izlazu iz TWT pojačavača dobija se predajni signal velike snage i frekvencije $f_{t}$ koji se pomoću talasovodnog sistema prenosi do antenske skretnice, koja preusmerava predajni signal ka anteni koja ga zrači u okolni prostor. RF generator generiše još jedan signal. To je signal lokalnog oscilatora koji ima frekvenciju za 30 MHz veću od predajne.

Eho-signal prima se preko iste antene i dovodi ponovo do antenske skretnice koja ga sada preko talasovodnog sistema preusmerava ka prijemniku radara. Frekvencija prijemnog signala, $f_{r e}$, može se izraziti na sledeći način:

$f_{r e}=f_{t}+f_{d}$

gde je $f_{d}$ Doplerova frekvencija usled kretanja cilja u odnosu na radar. Doplerova frekvencija može imati pozitivnu ili negativnu vrednost, $u$ zavisnosti od toga da li se cilj približava ili udaljava od radara.

Prijemni signal frkvencije $f_{\text {re }}$ prenosi se do mešača. Na drugi ulaz mešača dovodi se signal lokalnog oscilatora. $\mathrm{Na}$ izlazu iz mešača dobija se prijemni signal, čiji je spektar iz visokofrekventnog područja transliran u međufrekventno područje na $30 \mathrm{MHz}$. Dalje se ovaj signal pojačava, prvo u pretpojačavaču, a zatim u međufrekventnom pojačavaču. 


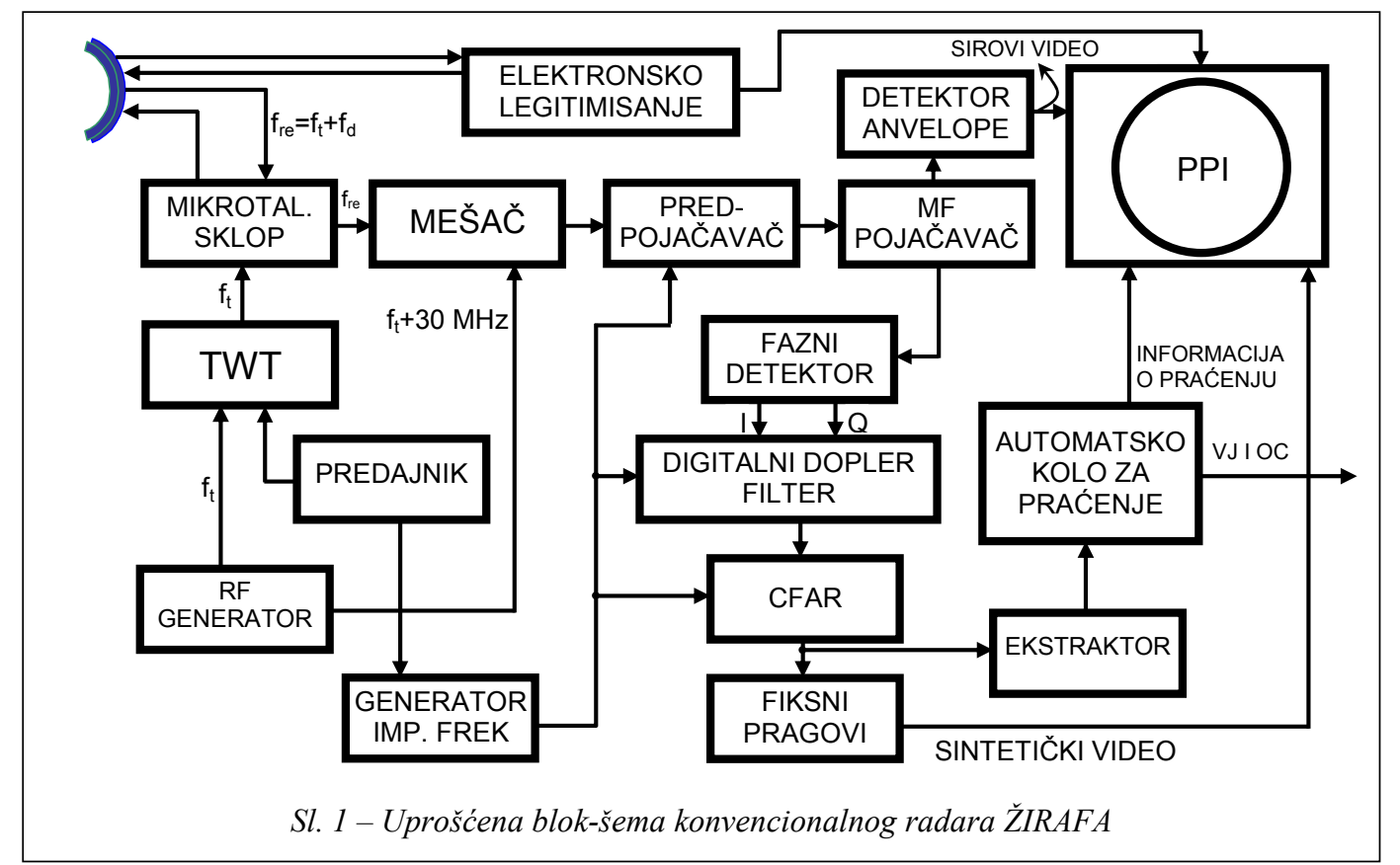

Od međufrekventnog pojačavača signal može dalje da se vodi ka detektoru anvelope ili ka faznom detektoru. Ako se preusmeri direktno na detektor anvelope (slika 2), signal neće biti digitalno obrađen i na panoramskom pokazivaču biće prikazan sirovi video signal. Taj signal sadrži refleksije od pokretnih ciljeva, ali i od nepokretnih ciljeva koji čine stalne odraze, tako da je uočavanje pokretnih ciljeva otežano. Ako postoji ometanje, ometački signali će se videti na ekranu pokazivača, što još više komplikuje situaciju. U operativnoj upotrebi posada uvek, pomoću odgovarajućeg tastera na upravljač- kom pultu, usmerava signal ka faznom detektoru i blokovima koji dodatno digitalno obrađuju signal. Na ulaz IQ-demodulatora dovodi se kompleksan signal, a rezultat su dva signala čije su faze pomerene za $90^{\circ}$. Signal obeležen sa I predstavlja realnu komponentu, a signal Q imaginarnu komponentu kompleksnog signala.

Pošto radar poseduje samo jedan jednokanalni A/D konvertor, signali u kvadraturi, I i Q, multipleksiraju se u vremenu da bi konverzija bila moguća. A/D konvertor je desetobitni i kvadraturne signale iz I i Q grane bira naizmenično, frekvencijom od $468 \mathrm{KHz}$.

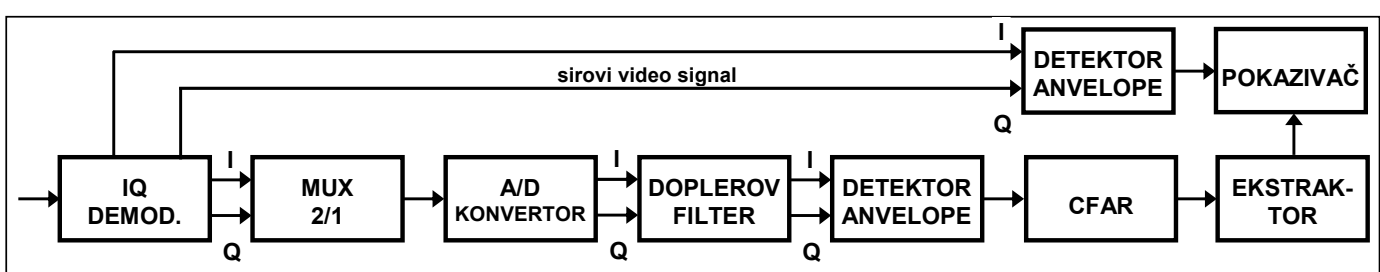

Sl. 2 - Blokovi za obradu signala radara ŽIRAFA 


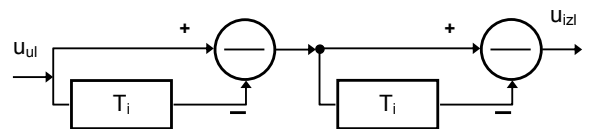

Sl. 3 -Dvoćelijski antiklaterski filter

Sledi blok nazvan Doplerov filter. To je visokopropusni filter šestog reda, koji se sastoji od tri filtera drugog reda, od kojih je prvi nerekurzivan s konstantnim koeficijentima, a drugi i treći su rekurzivni s promenljivim koeficijentima koji zavise od moda rada radara. Prvi Doplerov filter je tipičan dvoćelijski antiklaterski filter, čija struktura je prikazana na slici 3. Odziv ovog dvoćelijskog filtera na pobudu $\delta$ funkcijom je:

$$
h(t)=\delta(t)-2 \delta\left(t-T_{r}\right)+\delta\left(t-2 T_{r}\right)
$$

gde je $T_{r}$ perioda ponavljanja impulsa. Drugi i treći Doplerov filter ograničavaju apsolutne vrednosti ulaznih signala u određenim granicama. Nakon filtriranja neželjeni odrazi od tla i ostalih nepokretnih ciljeva su potisnuti, a ostaju samo signali reflektovani od pokretnih ciljeva.

Filtrirani signal vodi se na ulaz detektora. Detektor radara ŽIRAFA je kolo s konstantnom verovatnoćom lažnog alarma, ili skraćeno CFAR (Constant False Alarm Rate). Sačinjavaju ga kola za kašnjenje, akumulator detektora srednje vrednosti i ekstraktor odnosa (slika 4). CFAR detektor je tipa CA (cell averaging), što znači da se u njemu upoređuje vrednost signala u trenutnom binu daljine sa srednjom vrednošću signala u susednim binovima. U konkretnom slučaju, radi procene nivoa signala usrednjava se vrednost signala $u$ osam susednih binova daljine. Dobijena srednja vrednost signala (slika 4, tačka E) upoređuje se sa vrednošću signala u obrađivanom binu daljine (slika 4, bin daljine $X_{n}$ ) u ekstraktoru odnosa, deljenjem vrednosti signala $u$ obrađivanom binu daljine sa srednjom vrednošću signala. Prvo se izračunaju logaritam signala i logaritam srednje vrednosti. Traženi odnos dobija se posle oduzimanja logaritama i izračunavanja antilogaritma. Izračunavanje logaritma zasniva se na aproksimaciji logaritma osnove 2 . U zavisnosti od vrednosti dobijenog odnosa, donosi se odluka o tome da li je $\mathrm{u}$ obrađivanom binu daljine bio signal koji potiče od cilja ili se radilo o šumu.

Sledi blok nazvan ekstraktor podataka. Ekstraktor podataka izračunava koordinate centra cilja po daljini i azimutu i te koordinate prosleđuje na panoramski pokazivač, gde se cilj prikazuje kao svetla tačka sa određenim nivoom osvetljaja koji zavisi od amplitude reflektovanog signala. Podaci o koordinatama detektovanih ciljeva šalju se do bloka koji obavlja funkciju automatskog praćenja ciljeva (slika 1), a prosleđuju se i vatrenim jedinicama i operativnom centru.

Pokazivač radara ŽIRAFA je monohromatski i spada u grupu panoramskih pokazivača (Plan Polar Indicator - PPI). Prikazuje odraze od radarskih ciljeva i specijalne simbole. Informacija o ciljevima, koja se dobija pri prebrisavanju prostora u kojem se ti ciljevi nalaze, sadrži daljinu i azimut za svaki cilj posebno. Informacija o daljini dobija se iz video signala koji se prikazuje, a pravac, odnosno azimut, od digitalnog davača ugla azimuta koji se nalazi na anteni radara. 


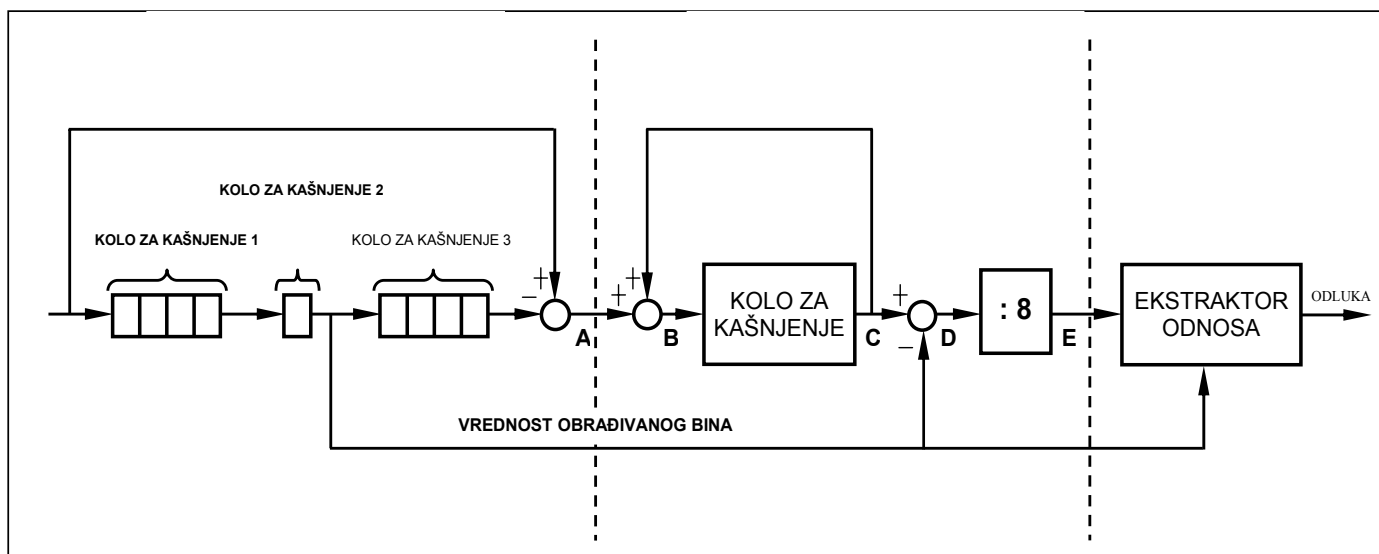

Primer:

Kada se obrađuje bin daljine broj 24, pomerački registar će imati sledeći sadržaj:

$$
\begin{array}{|l|l|l|l|l|l|l|l|l|}
\hline X_{28} & \mathbf{X}_{27} & \mathbf{X}_{26} & \mathbf{X}_{25} & \mathbf{X}_{24} & \mathbf{X}_{23} & \mathbf{X}_{22} & \mathbf{X}_{21} & \mathbf{X}_{20} \\
\hline
\end{array}
$$

A: $\quad X_{29}-X_{20}$

B: $\quad X_{20}+X_{21}+X_{22}+X_{23}+X_{24}+X_{25}+X_{26}+X_{27}+X_{28}+\left(X_{29}-X_{20}\right)$

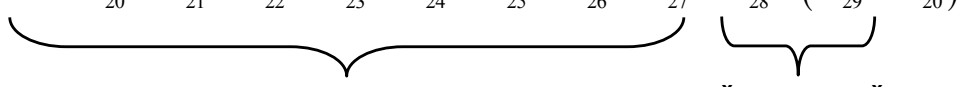

\section{SADRŽAJ U TAČKI C SADRŽAJ U TAČKI A}

C: $\quad X_{20}+X_{21}+X_{22}+X_{23}+X_{24}+X_{25}+X_{26}+X_{27}+X_{28}$

D: $\quad X_{20}+X_{21}+X_{22}+X_{23}+X_{25}+X_{26}+X_{27}+X_{28}$

$$
\begin{aligned}
& \text { E: } \quad \frac{D}{8} \\
& \text { ODNOS }=\log _{2}^{-1}\left(\log _{2} X_{n}-\log _{2} E\right)
\end{aligned}
$$

Sl. 4 - CFAR detektor radara ŽIRAFA sa vrednostima signala u karakterističnim tačkama

Ako se radar ŽIRAFA uporedi s drugim modernim radarima sličnog tipa može se reći da ima veoma skromne mogućnosti. Međutim, arhitektura radara ŽIRAFA dozvoljava određene modifikacije i unapređenje karakteristika pojedinih funkcionalnih blokova, a naročito blokova za digitalnu obradu signala i podataka.

\section{Projektovani softverski model funkcionalnih blokova konvencionalnog radara}

Projektovanjem softverskog modela funkcionalnih blokova prijemnika konvencionalnog radara stvara se pogodna platforma za unapređivanje njegovih karakteristika. U ovom radu projektovan je 
softverski model koji bi trebalo da, uz određena prilagođavanja konkretnom radarskom sistemu, bude primenjiv u svim tipovima konvencionalnih radara, kako $\mathrm{u}$ vojnoj, tako i u civilnoj upotrebi.

U prvoj fazi projektovanja zahtevano je da softverski model na približno istom nivou zadrži sve karakteristike hardverski realizovanog konvencionalnog radara. To znači da se ne sme smanjivati maksimalni domet, narušiti rezolucija po daljini i uglu, povećati verovatnoća lažnog alarma, smanjiti preciznost merenja koordinata ciljeva, kao i preciznost prikazivanja detektovanih ciljeva na softverskom modelu pokazivača.

U drugoj fazi projektovanja nastojano je da se, na osnovu projektovanih softverskih modela funkcionalnih blokova prijemnika konvencionalnog radara, unaprede njegove karakteristike, i to na tri načina. Prvi način podrazumeva promene algoritama obrade signala u projektovanim softverskim modelima funkcionalnih blokova radara. Time bi se unapredile karakteristike postojećeg Doplerovog filtera i procesora CFAR. Namera je da se projektuje Doplerov filter koji bi signale koji potiču od stalnih odraza potiskivao za više od $35 \mathrm{~dB}$. Kod konvencionalnih radara postoji problem detekcije ciljeva na bliskim međusobnim rastojanjima, reda rezolucione ćelije radara. Cilj je projektovanje softverskog modela procesora CFAR koji bi detektovao takve ciljeve, a da se pri tome ne poveća verovatnoća lažnog alarma. Drugi način unapređenja karakteristika podrazumeva uvođenje novih funkcija u projektovane blokove. Na taj način trebalo bi ostvariti funkciju selekcije ciljeva po brzini, kojom bi se ciljevi detektovali, a kasnije i pratili samo u zahtevanom opsegu brzine. Treći način je implementacija novih softverski modelovanih funkcionalnih blokova $\mathrm{s}$ funkcijama koje ne poseduje dati konvencionalni radar. Jedan od ciljeva ovog rada je projektovanje estimatora radijalne brzine, koji bi, na osnovu merenja Doplerove frekvencije reflektovanog radarskog signala, proračunavao brzinu detektovanog cilja.

Da bi se uspešno analizirale mogućnosti primene koncepta softverskog radara kod konvencionalnih radara, radi poboljšanja njihovih karakteristika, i da bi ta analiza bila verifikovana, projektovani su softverski modeli određenih funkcionalnih blokova, prethodno opisanog konvencionalnog radara ŽIRAFA. Blokovi koji su u ovom radu podlegli softverskom modelovanju vezani su za digitalnu obradu signala i podataka, a softverski je realizovan i panoramski pokazivač. Težnja je bila da softverski modeli u što većoj meri odgovaraju realnim karakteristikama hardverskih komponenata realnog radara. Projektovanje svih funkcionalnih blokova urađeno je u programskom paketu MATLAB.

Ako se uporede sl. 1 i 5 može se uočiti da su blokovi „digitalni Doplerov filter, CFAR procesor, fiksni pragovi i ekstraktor" zamenjeni jednim A/D konvertorom i blokom za obradu signala. Blok za obradu signala čine jedan robustni računar, ojačan DSP pločom, i softver sa softverskim modelima blokova za digitalnu obradu signala konvencionalnog radara. Elementi koji čine blok za obradu signala, odnosno softverski deo radarskog prijemnika, detaljnije su prikazani na sl. 6 . Pri softverskom modelovanju blokova težilo se da se njihovi nazivi, funkcije i redosled što bolje slažu sa originalnim blokovima upotrebljenog radara. 


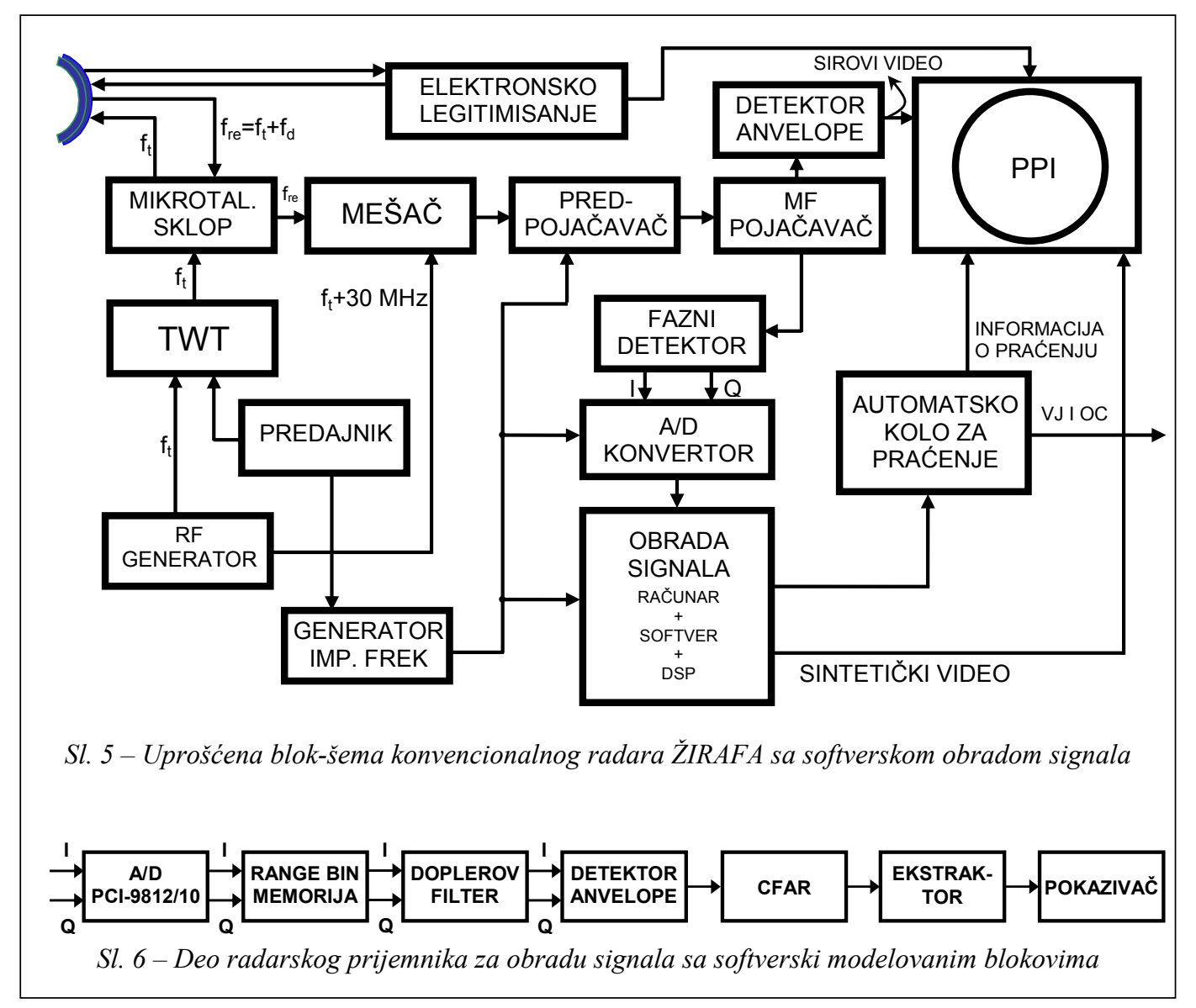

\section{Analogno-digitalna konverzija}

Zbog potrebe da se istovremeno odabira više signala, umesto postojećeg jednokanalnog A/D konvertora radara ŽIRAFA trebalo je upotrebiti jedan višekanalni A/D konvertor. A/D konverzija je obavljena pomoću kartice PCI-9812/10, na kojoj se nalazi jedan četvorokanalni A/D konvertor. Maksimalna frekvencija odabiranja po kanalu je 20 MHz. Ova kartica istovremeno odabira signale iz I i Q grane, koji dolaze sa IQ demodulatora, na trećem kanalu odabiraju se sinhronizacioni impulsi na izlazu iz generatora impulsne frekvencije radara, a četvrti kanal odabira tzv. ,impuls servera", koji daje informaciju o trenutku prolaska snopa antene preko nultog azimuta. Frekvencija odabiranja navedenih signala bila je $2 \mathrm{MHz}$, jer je trajanje sinhronizacionog impulsa $1 \mu \mathrm{s}$.

\section{Memorija RANGE BIN}

Sledi blok nazvan memorija RANGE BIN u koji se smeštaju podaci sa A/D konvertora i pripremaju za obradu u narednim blokovima. Ova memorija sadrži pakete podataka iz I i Q grane, složene kao na sl. 7. Svaki red predstavlja I 


\begin{tabular}{|c|c|c|c|c|c|c|}
\hline & & \multicolumn{5}{|c|}{ REDNI BROJ PREDAJNOG IMPULSA } \\
\hline & & 1. & 2. & 3. & $\ldots \ldots \ldots$ & $\mathrm{N}$ \\
\hline \multirow{5}{*}{ 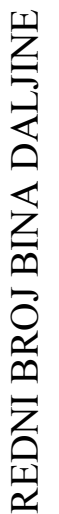 } & 1. & $\mathrm{I}, \mathrm{Q}(1,1)$ & $\mathrm{I}, \mathrm{Q}(1,2)$ & $\mathrm{I}, \mathrm{Q}(1,3)$ & $\ldots \ldots \ldots \ldots$ & $\mathrm{I}, \mathrm{Q}(1, \mathrm{~N})$ \\
\hline & 2. & $\mathrm{I}, \mathrm{Q}(2,1)$ & $\mathrm{I}, \mathrm{Q}(2,2)$ & $\mathrm{I}, \mathrm{Q}(2,3)$ & $\cdots$ & $\mathrm{I}, \mathrm{Q}(2, \mathrm{~N})$ \\
\hline & 3. & $\mathrm{I}, \mathrm{Q}(3,1)$ & $\mathrm{I}, \mathrm{Q}(2,3)$ & $\mathrm{I}, \mathrm{Q}(3,3)$ & $\ldots \ldots \ldots$ & $\mathrm{I}, \mathrm{Q}(3, \mathrm{~N})$ \\
\hline & $\vdots$ & & : & $\vdots$ & & $\vdots$ \\
\hline & M & $\mathrm{I}, \mathrm{Q}(\mathrm{M}, 1)$ & $\mathrm{I}, \mathrm{Q}(\mathrm{M}, 2)$ & $\mathrm{I}, \mathrm{Q}(\mathrm{M}, 3)$ & . & $\mathrm{I}, \mathrm{Q}(\mathrm{M}, \mathrm{N})$ \\
\hline
\end{tabular}

i Q odbirke istog bina daljine, a svaka kolona sadrži I i Q odbirke jednog predajnog impulsa. Rezolucija po daljini, označena sa $\Delta \mathrm{R}$, jeste parametar radara koji predstavlja sposobnost razdvajanja dva cilja na istoj uglovnoj koordinati. Radarski sistemi obično su projektovani tako da određuju daljinu cilja od minimalne vrednosti $R_{\min }$, do maksimalne $\mathrm{R}_{\max }$. Rastojanje od $\mathrm{R}_{\min }$ do $\mathrm{R}_{\max }$ podeljeno je na $M$ binova daljine. Širina svakog bina daljine je $\Delta \mathrm{R}$, a njihov broj se tada može dobiti prema izrazu:

$$
M=\frac{R_{\max }-R_{\min }}{\Delta R}
$$

Broj reflektovanih impulsa od jednog cilja u toku jednog prebrisavanja antene $-\mathrm{N}$, zavisi od frekvencije obrtanja antene $-\mathrm{f}_{\mathrm{s}}$, frekvencije ponavljanja impulsa $-f_{r}$, $i$ širine dijagrama zračenja antene $-\theta_{3 \mathrm{~dB}}$ i dat je u izrazu [3]:
$N=\frac{f_{r} \theta_{3 d B}}{2 \pi f_{s}}$

Ovakva matrica podataka generiše se za svaki položaj antene po azimutu [3].

\section{Doplerov filter}

Doplerov filter realizovan je kao transverzalni filter trećeg reda (sl. 8b), čiji je odziv na $\delta$ funkciju isti kao kod dvoćelijskog antiklaterskog filtera radara ŽIRAFA, prikazanog na sl. 3 i odgovara jednačini (2). Antiklaterski filter na bazi transverzalnog filtera može imati proizvoljan broj ćelija (slika 8a). Tada težinski koeficijenti transverzalnog filtera odgovaraju binominalnim koeficijentima s promenljivim znacima, a proračunavaju se prema jednačini:

$w_{k}=(-1)^{n-k}\left(\begin{array}{l}n \\ k\end{array}\right)=(-1)^{n-k} \frac{n !}{k !(n-k) !}$ 
gde je:

$-\mathrm{w}_{\mathrm{k}} \mathrm{k}$-ti težinski koeficijent,

$-n+1$ red transverzalnog filtera, $i$

- $\mathrm{k}$ redni broj težinskog koeficijenta

$(\mathrm{k} \in\{0,1, \ldots, \mathrm{n}\})$.

Ako se za n uzme vrednost 2, težin-

ski koeficijenti antiklaterskog transfer- zalnog filtera imaju vrednosti $1,-2$ i 1 (slika 8b). Frekvencijska karakteristika projektovanog filtera prikazana je na slici 9. Uočava se da ovakav antiklaterski filter potiskuje signale s malim Doplerovim pomakom za $35 \mathrm{~dB}$. Uvek se filtriraju vektori podataka iz istog bina daljine.

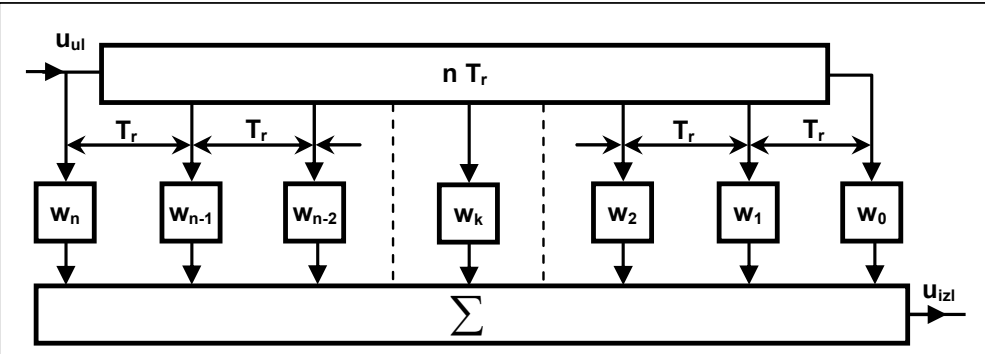

a) Filter reda $n+1$

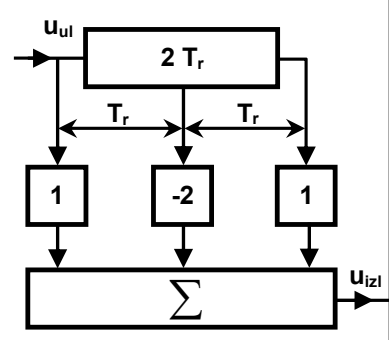

b) Filter trećeg reda

Sl. 8 - Realizacija Doplerovog filtera na bazi transverzalnog filtera
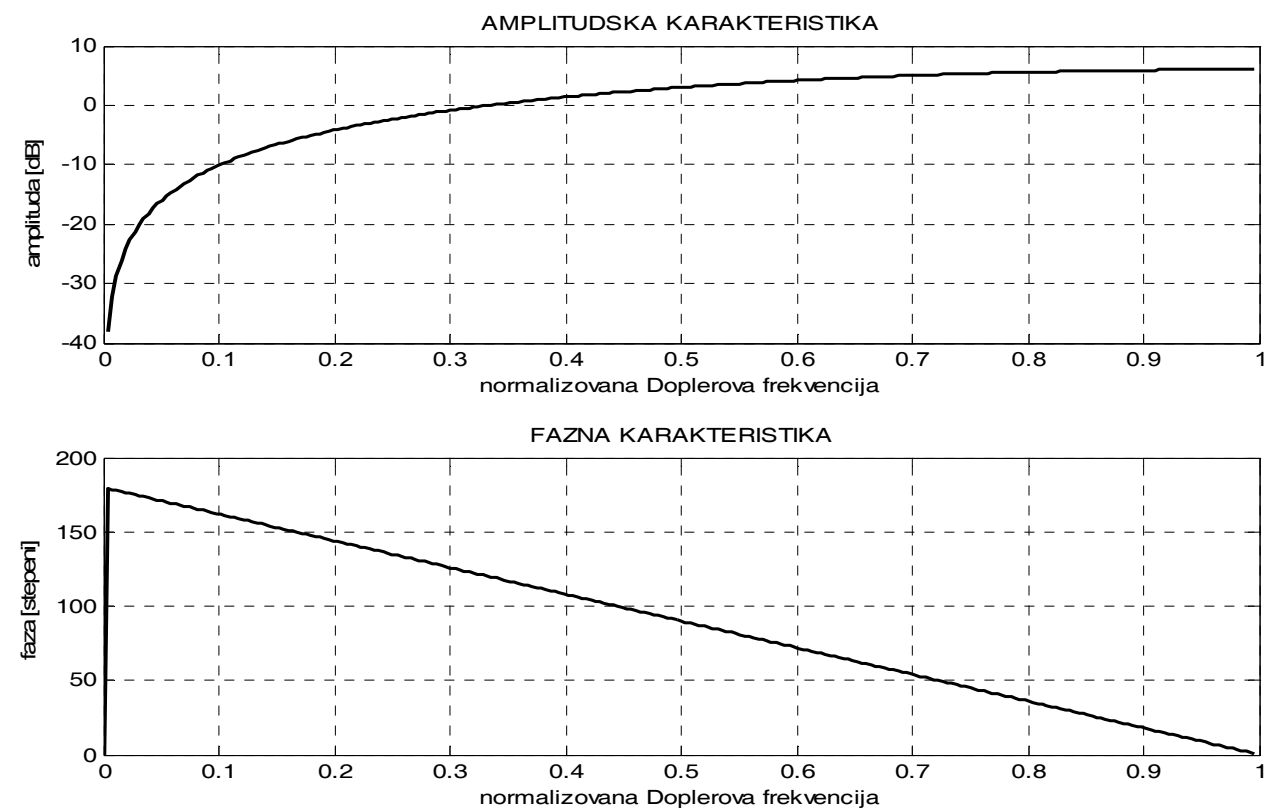

Sl. 9 - Amplitudska i fazna karakteristika Doplerovog filtera na bazi transverzalnog filtera sa koeficijentima 1, -2 i 1 


\section{Detektor anvelope i procesor CFAR}

Posle filtriranja signali se prosleđuju do detektora anvelope. Njegov zadatak je da za svaki filtrirani kompleksni par I, $\mathrm{Q}(\mathrm{m}, \mathrm{n})$ odredi modul po jednačini:

$$
X(m, n)=\sqrt{I(m, n)^{2}+Q(m, n)^{2}}
$$

gde je:

- I (m, n) - filtrirana realna komponenta signala $\mathrm{u}$ m-tom binu daljine, $n$-tog predajnog impulsa,

- Q $(\mathrm{m}, \mathrm{n})$ - filtrirana imaginarna komponenta signala $\mathrm{u} \mathrm{m}$-tom binu daljine, $\mathrm{n}$ tog predajnog impulsa, $\mathrm{i}$

- X $(\mathrm{m}, \mathrm{n})$ - signal na izlazu detektora anvelope $\mathrm{u} \mathrm{m}$-tom binu daljine, $\mathrm{n}$-tog predajnog impulsa.

$\mathrm{U}$ stvari, $\mathrm{X}(\mathrm{m}, \mathrm{n})$ predstavlja amplitudu filtriranog signala koji sada dolazi do detektora realizovanog u obliku procesora CFAR.
Procesor CFAR (Constant False Alarm Rate) koristi se kao detektor u radarskim prijemnicima za detekciju ciljeva u zoni osmatranja gde nisu poznati svi parametri statističke raspodele klatera ili tamo gde su oni nestacionarni. Blok-šema procesora CFAR [3] prikazana je na slici 10. Tri glavne tehnike koje se koriste pri realizaciji ovog procesora su:

- CA-CFAR (Cell Averaging CFAR),

- GO-CFAR (Greatest Of the selection logic CFAR) i

- SO-CFAR (Smallest Of the selection logic CFAR).

CA-CFAR je optimalan procesor CFAR kada je zona osmatranja homogena, tj. kada njegove ćelije imaju sadržaj sa identičnom raspodelom klatera. Procesor GOCFAR koristi se u situacijama kada treba detektovati više ciljeva u grupi, koji su veoma blizu jedan drugom. Ako ciljevi reflektuju signale koji su po amplitudi slični klateru u njihovoj blizini, za detekciju se koristi




procesor SO-CFAR koji sprečava prekomerno pojavljivanje lažnih detekcija ciljeva, odnosno pojavljivanje lažnih alarma. Bitni parametri svakog CFAR-a su:

- verovatnoća lažnog alarma $-\mathrm{P}_{\mathrm{fa}}$;

- veličina prozora detekcije - 2n; $\mathrm{ma}-\mathrm{Z}$

- srednja vrednost signala u ćelija$\mathrm{T}_{\mathrm{h}}, \mathrm{i}$

- faktor skaliranja praga detekcije -

- prag detekcije - S.

Faktor skaliranja praga detekcije, $\mathrm{T}_{\mathrm{h}}$, jeste konstanta kojom se postiže željena vrednost verovatnoće lažnog alarma za datu veličinu prozora detekcije 2n. Prozor detekcije sastoji se od dve grupe sa istim brojem ćelija koje se nalaze na suprotnim stranama $u$ odnosu na ćeliju čiji se sadržaj testira.

CA-CFAR obrađuje signale koje dobija od detektora anvelope, tako što usrednjava signale u $2 \mathrm{n}$ susednih binova daljine $\left(\mathrm{X}_{\mathrm{i}}\right)$ i dobijenu srednju vrednost upoređuje sa signalom $u$ binu daljine koji se testira (Y). Srednja vrednost signala u $2 \mathrm{n}$ susednih binova daljine data je u jednačini:

$Z=\frac{\sum_{i=1}^{n} X_{i}+\sum_{i=n+1}^{2 n} X_{i}}{2 n}=\frac{Y_{1}+Y_{2}}{2 n}$

Nivo praga detekcije, S, računa se za određenu verovatnoću lažnog alarma, $\mathrm{P}_{\mathrm{fa}}$. Verovatnoća lažnog alarma kod CA-CFAR-a, zavisi od faktora skaliranja praga detekcije, $T_{h}$, prema sledećoj jednačini [3]:

$P_{f a}=\left(1+T_{h}\right)^{-2 n}$

Lako se može izračunati da faktor skaliranja iznosi:
$T_{h}=\frac{1}{\sqrt[2 n]{P_{f a}}}-1$

Kod GO-CFAR procesora parame$\operatorname{tar} Z$ se dobija preko jednačine:

$Z=\frac{\max \left[\sum_{i=1}^{n} X_{i}, \sum_{i=n+1}^{2 n} X_{i}\right]}{n}=\frac{\max \left(Y_{1}, Y_{2}\right)}{n}$

a formula koja povezuje verovatnoću lažnog alarma i faktor skaliranja praga detekcije ima sledeći oblik [3]:

$P_{f a}=2\left(1+T_{h}\right)^{-n}-$

$-2 \sum_{i=0}^{n-1}\left(\begin{array}{c}n+i-1 \\ i\end{array}\right)\left(2+T_{h}\right)^{-(n+i)}$

U slučaju da je procesor SO-CFAR projektovan parametar $Z$ se dobija preko jednačine:

$Z=\frac{\min \left[\sum_{i=1}^{n} X_{i}, \sum_{i=n+1}^{2 n} X_{i}\right]}{n}=\frac{\min \left(Y_{1}, Y_{2}\right)}{n}$

a verovatnoća lažnog alarma [3]:

$P_{f a}=2 \sum_{i=0}^{n-1}\left(\begin{array}{c}n+i-1 \\ i\end{array}\right)\left(2+T_{h}\right)^{-(n+i)}$

U sva tri načina realizacije procesora CFAR, nivo praga detekcije, $S$, računa se kao proizvod faktora skaliranja praga detekcije i vrednosti parametra $Z$ po sledećoj jednačini:

$S=T_{h} \cdot Z$ 
Vrednosti faktora skaliranja

\begin{tabular}{|c|c|c|c|c|c|c|c|c|c|c|c|c|}
\hline \multirow{2}{*}{$P_{f a}$} & \multicolumn{3}{|c|}{$2 \mathrm{n}=8$} & \multicolumn{3}{c|}{$2 \mathrm{n}=16$} & \multicolumn{3}{c|}{$2 \mathrm{n}=24$} & \multicolumn{3}{c|}{$2 \mathrm{n}=32$} \\
\cline { 2 - 13 } & $\mathrm{T}_{\mathrm{CA}}$ & $\mathrm{T}_{\mathrm{GO}}$ & $\mathrm{T}_{\mathrm{SO}}$ & $\mathrm{T}_{\mathrm{CA}}$ & $\mathrm{T}_{\mathrm{GO}}$ & $\mathrm{T}_{\mathrm{SO}}$ & $\mathrm{T}_{\mathrm{CA}}$ & $\mathrm{T}_{\mathrm{GO}}$ & $\mathrm{T}_{\mathrm{SO}}$ & $\mathrm{T}_{\mathrm{CA}}$ & $\mathrm{T}_{\mathrm{GO}}$ & $\mathrm{T}_{\mathrm{SO}}$ \\
\hline $10^{-4}$ & 2,162 & 3,60 & 10,88 & 0,778 & 1,36 & 2,444 & 0,468 & 0,833 & 1,277 & 0,334 & 0,602 & 0,851 \\
\hline $10^{-6}$ & 4,623 & 7,78 & 36,00 & 1,371 & 2,42 & 5,131 & 0,778 & 1,400 & 2,347 & 0,540 & 0,983 & 1,475 \\
\hline $10^{-8}$ & 9,000 & 15,30 & 117,9 & 2,162 & 3,84 & 9,905 & 1,154 & 2,092 & 3,916 & 0,778 & 1,425 & 2,302 \\
\hline
\end{tabular}

Proračunate vrednosti za faktor skaliranja, u zavisnosti od vrednosti verovatnoće lažnog alarma i načina realizacije procesora CFAR, prikazane su u tabeli 2 .

Komparator, u okviru CFAR-a, upoređuje vrednost signala iz test-bina $(\mathrm{Y}) \mathrm{s}$ dobijenim pragom detekcije prema (14). Ako je $\mathrm{Y}>\mathrm{S}$ donosi se odluka da je $\mathrm{u}$ datom test-binu detektovan cilj sa unapred utvrđenom verovatnoćom lažnog alarma. Ukoliko se pri proračunu donese zaključak da je $\mathrm{Y}<\mathrm{S}$, u tom test-binu daljine ne nalazi se cilj.

\section{Ekstraktor i pokazivač}

U bloku ekstraktora na sl. 6 proračunavaju se koordinate centra cilja po azimutu i daljini za signale iz onih binova daljine u kojima je CFAR detektovao cilj. Zbog dimenzija samog cilja, ali i zbog širine antenskog snopa, postoji više uzastopnih detekcija u susednim ćelijama memorije RANGE BIN. Pod centrom cilja podrazumeva se onaj bin daljine i azimuta u kojem je vrednost susednih ćelija na izlazu iz CFAR-a maksimalna.

Da bi dobijeni podaci o koordinatama detektovanih ciljeva bili prikladno prikazani, softverski je modelovan panoramski pokazivač koji liči na realni pokazivač konvencionalnog radara. Softverski modelovani panoramski pokazivač prikazan je na sl. 11. Na njemu se detektovani ciljevi prikazuju kao svetle tačke. Posle svakog obrtaja antene slika na pokazivaču osvežava se novim podacima o ciljevima. Vizuelno se grubo može proceniti daljina cilja u kilometrima i azimut u stepenima, ali softverski se veoma lako mogu numerisati i obeležavati detektovani ciljevi. Takođe, na monitoru računara mogu se prikazati njihove tačne koordinate. Ako bi se ovde dodali podaci koje daje uređaj za elektronsko legitimisanje ciljeva, olakšalo bi se razvrstavanje ciljeva. Oni bi se, u zavisnosti od grupe kojoj pripadaju (vojni avion, civilni avion itd.), prikazivali različitim simbolima ili bojama.

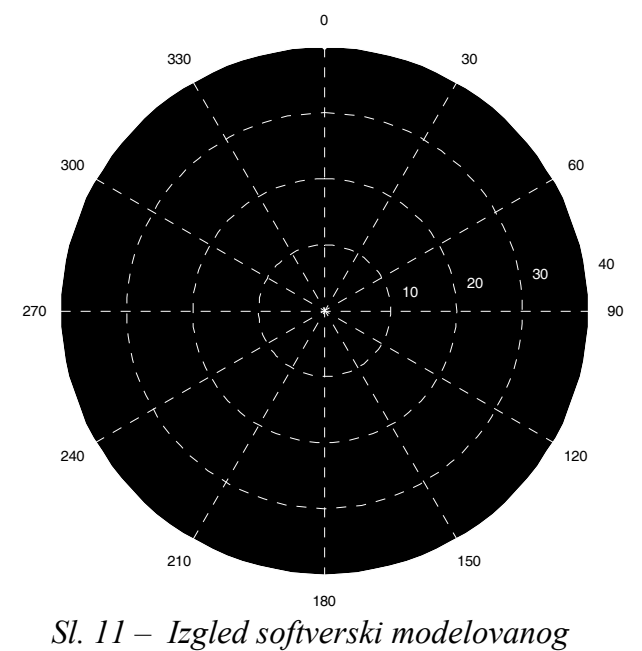
panoramskog pokazivača

\section{Zaključak}

Modelovanjem konvencionalnih radara kroz primenu koncepta softverskog radara mogu se poboljšati njihove performanse. Realizacijom ove ideje stvara se 
pogodna osnova za unapređivanje karakteristika postojećih konvencionalnih radara primenom modernih tehnika obrade radarskog signala. U radu su projektovani softverski modeli pojedinih funkcionalnih blokova radara, čime se stvorila pogodna platforma za poboljšanje performansi postojećih konvencionalnih radara. Primenom koncepta softverskog radara mogu se unaprediti karakteristike i povećati fleksibilnost konvencionalnih radara, kao i implementirati potpuno nove funkcije koje znatno unapređuju njegove performanse.
Literatura:

[1] Reed, J. H.: Software Radio, Comunications Enginering and Emerging Technologies, Prentice-Hall PTR, 2002.

[2] Grydeland, T.: Interferometric and high time-resolution observations of Naturally Enhanced Ion-Acoustic Echoes at the EISAT Svalbard Radar: Software radar and Incoherent Scattering, Doctor Scientiarum Dissertation, Faculty of Science Department of Pfysics, University of Tromso, 2003.

[3] Chung-Yi, C.: Modeling and simulation of a search radar receiver, Naval Postgraduate School Monterey California septembar 1996.

[4] Grydeland, T.: Software radar signal processing, Annales Geophysicale, 2004.

[5] Popović, M.: Digitalna obrada signala, Nauka, Beograd, 1996.

[6] Schleher, D. C.: MTI and Pulsed Doppler Radar, Artech House, USA Norwood, 1991. 